\title{
DESCRIPTION OF A NEW SPECIES OF RHAGADA FROM WESTERN AUSTRALIA.
}

\author{
By H. B. Preston, F.Z.S. \\ Read 10th April, 1908. \\ Rhagada Radleyt, n.sp.
}

Shell discoidal, depressed, white, painted above the periphery with two greyish-brown bands, and below with five bands of the same colour; whorls $4 \frac{1}{2}$, transversely marked with lines of growth, the last whorl descending; sutures well impressed; aperture rather oblique, roundly lunate; peristome expanded, scarcely reflexed; columella descending obliquely, expanded over and almost sealing the umbilicus and diffused above into a light parietal callus. Alt. 8·5, diam. maj. $15 \mathrm{~mm}$; aperture, alt. 6 , diam. $4 \mathrm{~mm}$.
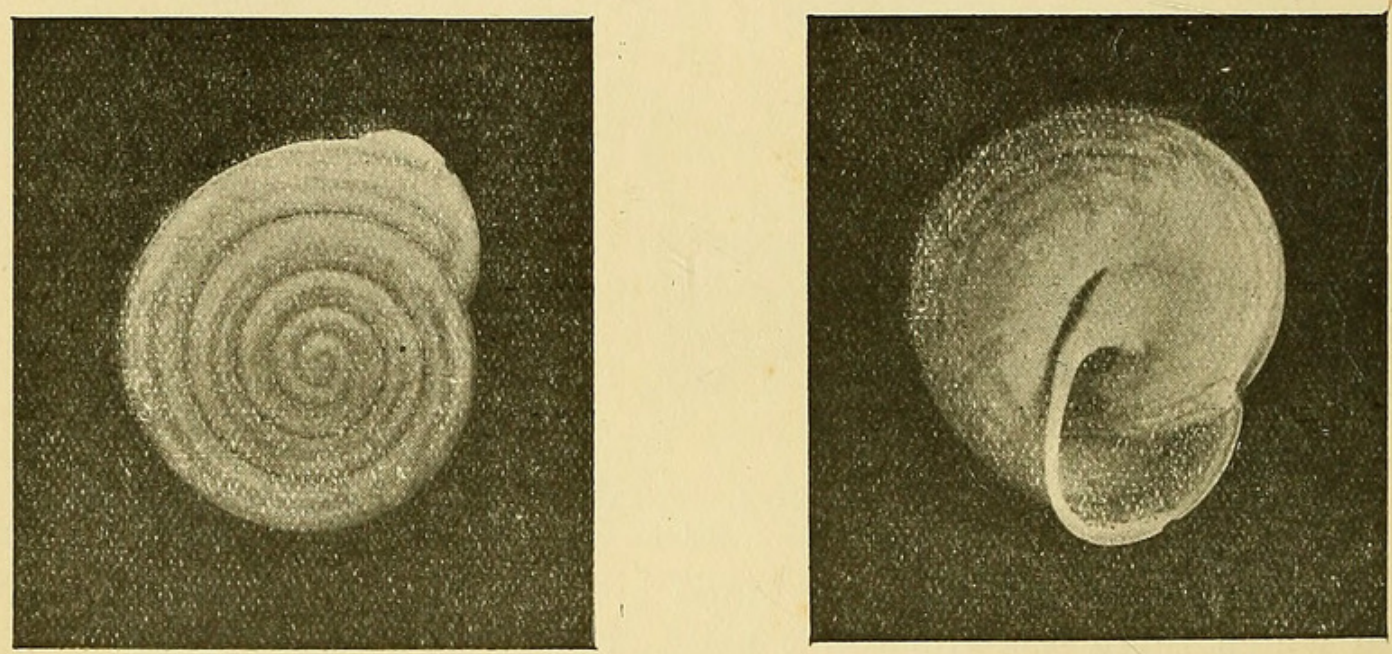

Hab.-Western Australia.

Allied to R. Reinga, Gray, but smaller, and much more depressed; the umbilicus also is not quite closed, as is invariably the case in that species. 


\section{$2 \mathrm{BHL}$ Biodiversity Heritage Library}

Preston, H B. 1908. "DESCRIPTION OF A NEW SPECIES OF RHAGADA FROM WESTERN AUSTRALIA." Proceedings of the Malacological Society of London 8, 120-120.

View This Item Online: https://www.biodiversitylibrary.org/item/100060

Permalink: https://www.biodiversitylibrary.org/partpdf/202981

\section{Holding Institution}

Field Museum of Natural History Library

\section{Sponsored by}

Smithsonian

\section{Copyright \& Reuse}

Copyright Status: Public domain. The BHL considers that this work is no longer under copyright protection.

This document was created from content at the Biodiversity Heritage Library, the world's largest open access digital library for biodiversity literature and archives. Visit BHL at https://www.biodiversitylibrary.org. 